INTERNATIONAL JOURNAL OF SCIENTIFIC RESEARCH

\title{
"A STUDY ON AN IMPACT OF ICT (INFORMATION COMMUNICATION TECHNOLOGY) ON SERVICE QUALITY OF LIBRARY MANAGEMENT: A QUALITATIVE APPROACH".
}

\author{
Library Science
}

\author{
Kajal \\ Hasmukhbhai \\ Patel
}

\author{
(Ph.D. Research Scholar) Hemchandracharya North Gujarat University, Patan.
}

\section{ABSTRACT}

Today's world is the era of information overloads. In Colleges and schools, libraries are mesh-up with databases. To maintain databases emerged as a big concern for Librarian. In library science, where now online journals, research papers and articles playing a major role in comparison to offline hardbound book, journals etc., It's a challenge to Librarian to deal with and to maintain a smooth handling of online database, its record keeping, Account maintenance, etc. Emergence of ICT (Information Communication Technology) in library science is working like a game changer in first look. But, through this research, an in-depth study was carried out to study an impact of ICT on various service quality dimensions of library science. Objective: To study an impact of ICT implementation on service quality of the Library management. Research methodology: Qualitative study. Data collection method: In-depth Interview. Sample unit: Librarian of Arts and Commerce College affiliated with Hemchandracharya North-Gujarat University. Sample Size: 5 Librarians. Conclusion: ICT has significant impact over all five dimensions of service quality. Due to implementation of ICT, task handlings and work efficiencies of Librarians has significantly improved. Librarians were highly satisfied with the usage of ICT software's. Managerial implication: Findings of this research paper may enlighten the usage of new technologies in the field of Library science. Further scope: The findings of this research can be useful to improve service quality of Library Science Management.

\section{KEYWORDS}

ICT (Information Communication Technology), Qualitative study, Service Quality and Library Science.

\section{INTRODUCTION:}

Libraries are service organizations, whose main task is linking the society with knowledge and information through their efficient services. High level of service quality has an important role in the development and distribution of knowledge and information. Every library is substantiated on librarians, who are trying to provide good service to users; who want to work with people and help them (Weingand 1997, 2). For this study, service means the activities provided by Slovenian public libraries. The unique function of libraries is to acquire, organize, offer for use and preserve publicly available material irrespective of the form in which it is packaged in such a way that, when it is needed, it can be found and put to use (Ryynänen 1999). Gupta (2003, 95-96) means that libraries are pressured by new sources of information and new ways of providing information to mobilize their resources and become self-reliant. Users' expectations are also increasing and their needs and wants are becoming diverse. Gupta (ibid) emphasizes the notion of services has been changed from mass customization to individualized service and a real challenge for library and information professionals is not to manage the collection, staff and technology but to turn these resources into efficient and quality services.

\section{Dimensions Service Quality.}

Zeithaml, Parasuraman and Berry found five dimensions customers use when evaluating service quality. They named their survey instrument SERVQUAL. In other words if the providers get these dimensions right, customers will hand over the keys to their loyalty. Because they'll have received service excellence. According to what's important to them.

\section{The five SERVQUAL dimensions are:}

TANGIBLES-Appearance of physical facilities, equipment, personnel, and communication materials.

RELIABILITY- Ability to perform the promised service dependably and accurately.

RESPONSIVENESS- Willingness to help customers and provide prompt service.

ASSURANCE- Knowledge and courtesy of employees and their ability to convey trust and confidence.

EMPATHY- Caring, individualized attention the firm provides its customers.

\section{Research Methodology:}

Research design: A qualitative research design is concerned with establishing answers to the why and how of the phenomenon in question (unlike quantitative). Due to this, qualitative research is often defined as being subjective (not objective), and findings are gathered in a written format as opposed to numerical.
Data collection method: Data has collected by In-depth Interview method. In-depth interviews are a qualitative data collection method that involves direct, one-on-one engagement with individual participants. In-depth interviewing can take place face-to-face, or - in some cases - over the phone. However, for the latter to be effective and to deliver reliable information, the interviewer must be highly skilled to prevent data loss.

Sample unit: Librarian of Arts and Commerce College affiliated with Hemchandracharya North-Gujarat University.

Sample size: Five college librarians of Arts and Commerce College affiliated with Hemchandracharya North-Gujarat University.

\section{OBJECTIVES:}

1. To study an impact of ICT implementation on service quality of the library management.

2. To ascertain that ICT implementation has to reduce stress live of librarian.

\section{Findings:}

Tangibles

1. By implementing ICT in the library, the appearance of the library increase?

Ans: All the five librarians were highly satisfied with the statement. They said, now libraries look sophisticated and well-managed.

\section{Reliability:}

2. Are you keeping users informed when services will be performed? Librarians said, because of ICT, they are able to give prompt responses to the users. They were all agreed on the database management software having significant impact on tracking of services.

3. Providing services without any mistakes?

All librarians were highly agreed with this statement. They said that yes, not only mistakes gets reduced, also rectification and tracking of mistakes became easier and faster.

4. ICT implementation helpful to build trust among user? All librarians were agreed with this statement. They said due to electronic record keeping, the user is getting updated information and rely on database information.

5. Performing services right on first time? All librarians were agreed on this statement. Due to ICT, all manual works are now transferring to electronic one. So, error rate has significantly reduced.

6. Providing services at the promised time All librarians were agreed on this statement. Due to ICT, they feel 
less job burden and mentally free. They all realized significant increase in work efficiency. Service time has reduced.

\section{Responsiveness:}

7. Librarians feel capable to respond to users' requests. They were all agreed with this statement. Librarians were enjoying to dealing with user and delivering better services. Personalization, customization increases. Database management helps a lot.

8. Be ready to provide prompt service.

They were all agreed with this statement. They said due to the implementation of ICT, service delivery time has significantly reduced. Now they all are comfortable to provide interim services and waiting time has significantly reduced.

9. Be willing to help users

They were all agreed with this statement. They said due to the implementation of ICT, their work efficiency has increased and they feel comfortable and enjoy dealing with number of users.

\section{Assurance:}

10. Employees should be able to build confidence into users? They were all agreed with this statement.Due to ICT implementation, digitalization of resources has properly maintained. Users and librarians both rely on database. It built confidence in to users.

11. Make users feel secure about transactions?

They were all agreed with this statement. Due to ICT implementation, error rate is reduced. Users feel confidence on database management system. Also, the database is kept confidential which develop a sense of security in users.

12. Be courteous in contact with users?

They were all agreed with this statement. They said all workload now shifted to electronically, also well manage. They feel free and respond to customers more politely and courteous.

13. Have the knowledge to answer user questions?

They were all agreed with this statement. They said proper training has provided to them by university. Also, they did proper certification programs of using library software's which helps them a lot. They also said that ICT usage is not difficult, it's easy to understand. Yes, they all feel comfortable to resolve customers query.

\section{Empathy:}

14. Individualized attention the library provides to its users?

They were all agreed with this statement. College library has convenient working hours. Staff and students have sufficient time space. They said now they may pay more attention to resolve customer's queries. Now, whole Library management is automated self-driven system. Now, the Librarian may add a more human touch to the system and work like a facilitator between self-running automated system and the users.

15. Employees should be paying attention to each individual user? They were all agreed with this statement. The librarian may add value by interacting with the users.

Due to ICT, librarians get empowered and having sufficient time to interact with users. Even, now they feel happy to resolving queries for users and also, to train them.

\section{Stress level.}

16. By implementing ICT in the library, stress level of employees has reduced?

They were all agreed with this statement. They said implementation of ICT has worked like a game changer. Due to it, not only work efficiency has increased, but also library management has work like a self-reliant. Tracking of information and rectifications of error became very fast. Now, Librarians can able to resolve queries of users. Librarian feels relax.

\section{CONCLUSION:}

ICT has significant impact over all five dimensions of service quality. The tangibility of library service was improved. Libraries now look more sophisticated and well-managed.Due to proper database management and proper tracking of issue and return of books, significant rise in Reliability of services has observed. Also, bar code scanning technique, significant reduction in service time was observed. After stunning result, it is concluded that ICT has a positive and significant impact on library management. Also, the drastic decrease in error rate in the system. Trustworthiness among users is also increased. Even, we can say that because of ICT human errors are eliminated from the system.

ICT having significant impact on the responsiveness of the librarians. The librarian is now giving prompt responses and having fast update of accounts. ICT also increases assurance of database. Librarians are now dependent more over artificial intelligence and software's which made things very easy. ICT having significant impact over to reduce stress levels of librarians. Overall, I conclude that ICT having significant and transforming impact on the service quality of library management and it reduces the stress level librarian in many folds. Usage of online journal and database has tremendous increases; simultaneously there are challenges to maintain records and database of user of it. Implementation of ICT has empowered the librarian and made them self-reliant. Also, ICT has significant impact over Database management and Tracking system. Now, to maintain registers of issue and returns of books is not a burden to the librarian. ICT gives on-time tracking system.

Managerial implications: This research paper will be helpful to study an impact of change in education, Information and Knowledge world. Here, we see how technology replacing a manual job and how its change the whole scenario. Now, World is facing Information overloads and Knowledge sharing happen at lighting speed, So, definitely technology especial artificial intelligence will play more and more crucial role in all areas. Take away of this research paper is to how we can design training programmes for both to users and service providers so that; we can make such change easier and more beneficial to education world.

\section{REFERENCES}

1. Atan, H., Halim, A., Guan, S.K., Idrus, R.M., 2002. Science educational software in Malaysian Smart Schools: an evaluation of pedagogical and communicative dimension. In: Man, R., Hashim, Y. (Eds.), ICT in Education and Training: Trend and Issues. Malaysian Educational Technology Society, Kuala Lumpur, pp. 389-394.

2. Bobowick, B, 2001. Building technology expertise among teachers. In: Kallick, B, Wilson III, J.M. (Eds.), Information Technology for Schools. Jossey-Bass, San Francisco, CA, pp. 75-92

3. Brindley, D. L. J. (2009). Challenges for great libraries in the age of the digital native. Amsterdam: IOS Press.

Cleveland, A. (2004) Library anxiety: A decade of empirical research, Library Review, $53(3), 177-185$

5. Cohen, J. (1988). Statistical Power Analysis for the Behavioral Sciences. (2nd ed.) Hillsdale, New Jersey: Erlbaum.

6. Cohen, J. (1990). Things I have learned (so far). American Psychologist, 45, 1304-1312. Kanjilal, Uma, \& Ghosh, S.B. Developing e-Learning prototype for library management - a case study. Available online at /http:// www. unige. ch/ biblio/ ses/ IFLA/sat1-Ghosh.pdfS

8. Karisiddappa, C.R. (2004). Library and information science curriculum for the developing countries. World Library and Information Congress: 70th IFLA General Conference and Council, 22-27 August 2004, Buenos Aires, Argentina, available online at/http://www.ifla.org/IV/ifla70/papers/ 062e-Karisiddappa.pdfS

9. Parasuraman, A.; Zeithaml; Valarie A.; Berry, Leonard L. A conceptual model of service

10. Parasuraman, A.; Zeithaml; Valarie A.; Berry, Leonard L. SERVQUAL: a multiple-item scale for measuring consumer perceptions of service quality. // Journal of Retailing 64 1(1988), 12-40.

11. Patra, B.K.(2008) The Role Of Information and Communication Technology on Management and Services Of Academic Libraries. Techno India Group Research Management

12. Pillow, A. (2003): Database Electronic Resources http:// www. libunicletu/ science/ instruction/glossary.html Retrieved on the 14th November 2009.quality and its implications for future research. // The Journal of Marketing 49, 4(1985), 41-50.

13. Rana, H.K. (2009): Impact of Information and Communication Technology on Academic Libraries in Punjab. Source: http/www.goarticles.com/cgi-bin/showa/cgi? $=1239032$ Retrieved $28 / 08 / 2009$.

14. Ubogu, F. N. (2000): The Paperless Society: Farce or Reality. African Journal Of Library And, Archives And Information Science. 10(1), 13-21.

15. Zakaria, Zaherawati. Service quality dimensions in public library: Northern area experienced.// Journal of Social Sciences 7,2(2011), 265-270.

16. Zeithaml Valarie A.; Parasuraman, A.; Berry, Leonard L. Problems and strategies in services marketing. // Journal of Marketing 49, 2(1985), 33-46.

17. Zeithaml, Valarie A.; Berry, Leonard L.; Parasuraman, A. 1988. Communication and control processes in the delivery of service quality. // Journal of Marketing 52, 2(1988), $35-48$

18. Zeithaml, Valarie A.; Bitner, Mary Jo. Services marketing: integrating user focus across the firm. Boston, MA: McGraw-Hill/Irwin, 2003.

19. Zeithaml, Valarie A.; Parasuraman, A.; Berry, Leonard L. Delivering quality service: balancing user perceptions and expectations. New York: Free Press, 1990. 